\title{
Red cell hypoplasia, thrombocytosis, and leucocytosis: myelodysplastic and proliferative syndrome
}

\author{
A CRAIG, C G GEARY, E M LOVE, J LIU-YIN \\ From the Department of Haematology, Royal Infirmary, Manchester
}

SUMMARY Three patients with chronic red cell aplasia also showed thrombocytosis or granulocytosis, or both. All had morphological evidence of myelodysplasia on examination of bone marrow aspirate but none had a detectable chromosomal abnormality. These patients seem to provide evidence of a separate entity within the spectrum of myelodysplastic and myeloproliferative disease.

Chronic red cell aplasia in adults is commonly due to autoimmune disease, ' or to an intrinsic defect either in the pluripotent haemopoietic stem cell or in the maturation of its erythroid lineage. In the latter group evolution into marrow hypoplasia or leukaemia may occur. ${ }^{2}$ We describe three cases in which the clinical manifestations of the disease were those of chronic anaemia due to red cell hypoplasia, but in whom the morphological picture was later suggestive of a chronic myeloproliferative or myelodysplastic disease.

\section{Case reports}

CASE 1

A 49 year old man presented in 1981 with symptoms of a hiatus hernia. He had a history of occupational exposure to trichlorethylene. Physical examination yielded normal results apart from pallor. Routine testing showed a haemoglobin concentration of 7.6 $\mathrm{g} / \mathrm{dl}$, mean cell volume (MCV) $109 \mathrm{fl}$, with a dimorphic blood picture; a white cell count of $4.4 \times 10^{9} / 1$ with a normal differential and a platelet count of $332 \times 10^{9} / 1$. Reticulocytes of $2 \cdot 4 \%$, erythrocyte sedimentation rate (ESR) of $36 \mathrm{~mm} /$ first hour, serum $B_{12}$, serum, and red cell folate and serum iron concentrations were all normal, as were a biochemical screen and thyroid function tests. Direct antiglobulin test (DAT) and Ham's test were negative. The marrow karyotype was 46XY. There was a polyclonal increase in IgG and IgA; no autoantibodies were detected. The diagnosis was uncertain at this stage and the patient was kept under close review, requiring blood transfusions every six to eight weeks. Eleven months later a repeat bone

Accepted for publication 24 May 1988 marrow aspirate showed severe erythroid hypoplasia, with reduced overall cellularity. A trial of oxymetholone had no effect on the patient's transfusion requirement.

Further bone marrow examination confirmed erythroid aplasia with dysplasia of megakaryocyte and granulocyte precursors, and 7-10\% myeloblasts. During 1985-6 the peripheral leucocyte count rose and circulating granulocyte precursors were noted, with an occasional modest thrombocytosis (platelets numbered about $\left.530 \times 10^{9} / 1\right)$. Neither Cis-retinoic acid nor low dose cytosine arabinoside improved erythropoiesis. The total white cell count continues to fluctuate between $25-80 \times 10^{9} / 1$, with $5-15 \%$ myeloblasts. At the time of writing the patient had early signs of iron overload despite treatment with desferrioxamine, but he had few symptoms that could be attributed directly to his leukaemia.

\section{CASE 2}

A man of 62 presented in 1982 with a history of anaemia for several months. Physical examination showed pallor and a liver palpable $3 \mathrm{~cm}$ below the costal margin. Haemoglobin concentration was $8.4 \mathrm{~g} /$ dl, white cell count was $4.2 \times 10^{9} / 1$ (neutrophils $3.44 \times$ $10^{9} / 1$ ), platelets $292 \times 10^{9} / 1, \mathrm{MCV} 85 \mathrm{fl}$, reticulocytes less than $1 \%$ ). Bone marrow was hypercellular, with dysplasia of granulopoiesis and thrombopoiesis and profound erythroid hypoplasia; a few "megaloblastoid" erythroid cells were intermittently present. Sucrose lysis test was positive once only; Ham's test yielded negative results. Immunoglobulin pattern, serum $B_{12}$, and folate assays were all normal. Repeated cytogenetic analysis showed a normal 46 XY karyotype. Attempts at bone marrow colony culture were unsuccessful. He required regular blood trans- 
fusions from the time of diagnosis and there was no perceptible response to androgens, or to low dose cytosine arabinoside. In 1985, however, he developed Guillain-Barré syndrome which was treated with adrenocorticotrophic hormone injections and plasma exchange. He also received a single course of " $\frac{1}{2} D A T$ " (cytosine, thioguanine, and half dose dose daunorubicin). During this period his transfusion requirement lessened, although the improvement was not maintained. Splenomegaly increased and he developed signs of iron overload with a serum ferritin concentration of $>4000 \mu / 1$. His leucocyte and platelet counts rose; in early 1987 the total leucocyte count was $31.8 \times 10^{9} / 1$ (neutrophils $28.9 \times 10^{9} / 1$, monocytes 1.59 $\times 10^{9} / 1$, and basophils $0.95 \times 10^{9} / 1$ ), platelets $543 \times$ $10^{9} / 1$. The neutrophil alkaline phosphatase (NAP) score was 111 per 100 neutrophils (normal $=15-100$ ). Bone marrow blasts were between 5 and $10 \%$. A course of Cis-retinoic acid improved his leucocyte and platelet counts, but had no effect on the haemoglobin concentration. Shortly before his death from cardiac failure in October 1987 his platelet count fell and the white cell count rose to $58 \times 10^{9} / 1$ (myeloblasts $6.38 \times$ $10^{9} / 1$ and basophils $\left.9.8 \times 10^{9} / 1\right)$. At necropsy, there was evidence of severe haemosiderosis. The spleen weighed $3 \cdot 1 \mathrm{~kg}$ and showed infiltration by granulocytic cells.

\section{CASE 3}

A 75 year old woman presented in 1985 with six months of lethargy; she was clinically anaemic but had no splenomegaly. Her medical and drug history were unremarkable. She had a macrocytic anaemia (haemoglobin concentration of $5 \mathrm{~g} / \mathrm{dl}$ ) which did not respond to empirical treatment with vitamin $B_{12}$ and folic acid.

On further investigation her haemoglobin concentration was $3.5 \mathrm{~g} / \mathrm{dl}$ and her MCV $131 \mathrm{fl}$, with some teardrop cells. The white cell count was $7.4 \times 10^{9} / 1$ (neutrophils $6.7 \times 10^{9} / 1$ ), the platelet count normal, reticulocytes $1.2 \%$ ESR $55 \mathrm{~mm} /$ first hour, the DAT negative. Sucrose lysis test was also negative. Serum $B_{12}$ and folate concentrations, were normal. Biochemical profile showed no specific abnormality. Immunoglobulin concentrations were normal apart from a minimal increase in IgA; serum electrophoresis was normal and there were no autoantibodies. Thyroid function was normal. There was no evidence of thymoma on chest $x$-ray picture or computed tomography scan. Bone marrow examination showed erythroid hypoplasia with myelodysplasia. Chromosome analysis was normal (46XX) and granulocyte-macrophage colony forming cells (GM-CFCs) were greatly reduced at 2 per $10^{5}$ cells.

After blood transfusion she was treated with prednisolone and her haemoglobin concentration rose to
$10 \mathrm{~g} / \mathrm{dl}$. Six months later the platelet count rose to 1088 $\times 10^{9} / 1$ and the haemoglobin concentration began to fall (haemoglobin concentration $8 \mathrm{~g} / \mathrm{dl}, \mathrm{MCV} 120 \mathrm{fl}$, white cell count $41 \times 10^{9} / 1$, with neutrophils $38.5 \times$ $10^{9} / 1$, monocytes $0.4 \times 10^{9} / 1$, and retics $>1 \%$ ). There was no evidence of haemorrhage, and vitamin $B_{12}$ and folate estimations remained normal. NAP score reached 49/100 neutrophils. She developed signs of proximal myopathy induced by steroids and these were discontinued. A repeat marrow aspirate showed relapsing red cell aplasia. GM-CFCs were "low normal" ( 32 per $10^{5}$ cells) and BFU-E very low at 3 per $10^{5}$ cells. Because of the patient's frail state it was felt that simple supportive treatment would be appropriate, and she was maintained on regular blood transfusions. She developed evidence of a monocytic leukaemia (white cell count $22 \times 10^{9} / 1$, with monocytes $13.2 \times$ $10^{9} / 1$, a platelet count of $500 \times 10^{9} / 1$, and haemoglobin concentration $6 \mathrm{~g} / \mathrm{dl}$ ) and died 30 months after the first diagnosis.

\section{Discussion}

These three patients have several features in common; they all originally presented with a chronic normochromic normocytic or macrocytic anaemia, reflecting a profound or fluctuating red cell hypoplasia, with subsequent development of thrombocytosis or granulocytosis, or both, in marrow and peripheral blood, with morphology suggesting myelodysplasia.

Erythroid hypoplasia and thrombocytosis, ${ }^{3}$ but not granulocytosis, ${ }^{4}$ have been described together in the context of the 5q-syndrome, while sideroblastic anaemia and thrombocytosis have been associated with chromosomal abnormalities. ${ }^{5}$ Repeated cytogenetic analyses in our cases, however, showed normal karyotypes, reported to be associated with longer survival in myelodysplastic syndromes. ${ }^{6}$ Our first patient has survived six years since diagnosis, while case 2 died of cardiac failure due to iron overload after five and a half years. Nevertheless, all our cases showed distinctive bone marrow abnormalities suggestive of myelodysplasia; indeed, when erythroblasts were detected in the marrow of case 2 , they were "megaloblastoid" and the marrow of this patient might then be deemed to have exhibited trilineage myelodysplasia. The persistent presence of immature cells in the blood of two patients in the absence of infection is also suggestive of an intrinsic bone marrow disorder. Case 3 differed somewhat from the others in that the red cell hypoplasia fluctuated, though transfusions were required for long periods.

Cases 2 and 3 showed some response to corticosteroids, though neither showed any other evidence of autoimmune disease. This is of interest in the light of the finding of Bagby et $\mathrm{al}^{7}$ that some cases of 
myelodysplasia show partial response to high doses of corticosteroids. Only in case 3 was the improvement in haemoglobin sustained for any length of time, although the thrombocytosis persisted and the patient relapsed while receiving steroids.

Red cell aplasia is recognised as a preleukaemic disorder: for example, Dumont found that 17 of $38 \mathrm{de}$ novo cases of chronic red cell aplasia eventually developed acute leukaemia. (Dumont J. Proceedings of the XV Congress of the International Society for Haematology, Jerusalem 1974). In a recent review of the literature, however, Fitchen found that the overall incidence of leukaemia in this syndrome was only $7 \%{ }^{8}$ Case 2 developed acute leukaemia shortly before his death from cardiac failure, and case 1 has had a peripheral blast count of the order of $3 \times 10^{9} / 1$ for two years. There are anecdotal reports of red cell aplasia complicating both chronic granulocytic leukaemia ${ }^{9}$ and agnogenic myeloid metaplasia. ${ }^{10}$ Our patients had neither the $\mathrm{Ph}$ chromosome nor a clinically important amount of reticulin on bone marrow trephine biopsy.

These cases are of interest because they seem to exhibit features of both myeloproliferative and myelodysplastic disease and are difficult to place within existing classifications of haematological malignancies. In a recent review of the morphological features of stem cell disorders, Weatherall concludes that it is quite common to encounter cases which are not easily classified within the current nosology of these syndromes." The above cases of red cell hypoplasia accompanied by proliferative features in other cell lines probably fall within the spectrum of what has previously been called "unclassifiable myeloproliferative disease".

\section{References}

1 Krantz SB. Pure red-cell aplasia. N Engl J Med 1974;291:345.

2 Fitchen JH. Pure red cell aplasia: a pre-leukaemic state? In: Bagby CC, ed. The preleukaemic syndrome. CRC Press, 1985:63-71.

3 Kerkhofs H, Hagemeyer A, Leeksma CHW, et al. The 5qchromosome abnormality in haematological disorders: a collaborative study of 34 cases from the Netherlands. $\mathrm{Br} J$ Haematol 1982;52:365-81.

4 Nimer SD, Golde DW. The 5q-abnormality. Blood 1987;1 1705-12.

5 Carrol AJ, Poon M-C, Robinson NG, Crist WM. Sideroblastic anaemia associated with thrombocytosis and a chromosome 3 abnormality. Cancer Genet Cytogenet 1986;22:183-7.

6 Yunis JJ, Rydell RE, Oken MM, Arnesen MA, Mayer MD, Lobel $M$. Refined chromosome analysis as an independent prognostic indicator in de novo myelodysplastic syndromes. Blood 1986;67:1721-31.

7 Bagby GC. Treatment of patients with the pre-leukaemic syndrome. In: The preleukaemic syndrome. CRC Press, 1985:219.

8 Fitchen JH. Pure red cell aplasia-a pre-leukaemic state? In: The preleukaemic syndrome. CRC Press, 1985:3-71.

9 Dessypris EN, McKee CL, Metantonakis C, Teliacos M, Krantz SB. Red cell aplasia and chronic granulocytic leukaemia. $\mathrm{Br} J$ Haematol 1981;48:217-25.

10 Bentley SA, Murray KH, Lewis SM, Roberts PD. Erythroid hypoplasia in myelofibrosis: a feature associated with blastic transformation. Br J Haemol 1977;36:41-7.

11 Weatherall DJ. Classification of stem cell disorders. In: Oxford textbook of Medicine OUP, 1987:19-15.

Requestions for reprints to: $\operatorname{Dr} C$ G Geary, Consultan Haematologist, Manchester Royal Infirmary, Oxford Road Manchester M13 9WL, England. 